\title{
Similarities in modi operandi of institutional and non-institutional child sexual offending:
} Systematic case comparisons

\author{
Natalie Martschuk and Jane Goodman-Delahunty
}

Faculty of Business, Justice, and Behavioural Sciences, Charles Sturt University, Manly, Australia

$$
\text { Martine Powell and Nina Westera }{ }^{1}
$$

Centre for Investigative Interviewing, Griffith Criminology Institute, Griffith University, Brisbane, Australia

\section{Acknowledgements:}

This research was supported by funding from the Royal Commission into Institutional Responses to Child Sexual Abuse to Martine B. Powell, Jane Goodman-Delahunty and Nina J. Westera. We are grateful to Rhiannon Fogliati, Alexandra Lonergan, Melissa Martin and Ida Nguyen for their excellent assistance in manually reviewing and coding the prosecution files.

\footnotetext{
${ }^{1}$ Deceased May 25, 2017
} 


\begin{abstract}
Little is known about the extent to which institutional child sex offending differs from noninstitutional offending. Strategies to secure the compliance of child victims were systematically compared to compare the modi operandi (prior to, during and following abuse), and the type of power (intimate, aggressive, coercive) applied by child sexual offenders in institutional versus noninstitutional settings. A sample of 59 of the most recent child sexual abuse cases referred for prosecution in three Australian states was manually reviewed and coded. Of these, six were cases of institutional abuse, one of which involved cross-over offending. Based on complainant age and gender and patterns in offending behaviors, institutional cases were matched with cases of noninstitutional abuse. Complainants of both genders ranged in age from 5-16 years at abuse onset. Offenders were male family members or friends, priests, an employer and one female school teacher. Results demonstrated commonalities in the modi operandi and grooming methods applied in institutional and non-institutional contexts. Implications for abuse prevention are summarized.
\end{abstract}

Keywords: child sexual abuse; institutional child sexual abuse; grooming; modus operandi; pragmatic psychology; paired cases; case study 


\section{Similarities in modi operandi of institutional and non-institutional child sexual offending: Systematic case comparisons}

Sexual abuse of children within institutions (e.g., schools, churches, orphanages, and sport clubs) has become a major concern over the past few decades, with survivors disclosing both recent and historical experiences (Independent Inquiry into Child Sexual Abuse, 2016; Royal Commission into Institutional Responses to Child Sexual Abuse [RCIRCSA], 2017a; Terry, 2008). An institution is a "public or private body, agency, association, club, institution organisation or other entity or group of entities of any kind (whether incorporated or unincorporated), $[\ldots]$ that provides, or has any time provided activities, facilities, programs or services of any kind that provide a means through which adults have contact with children" (RCIRCSA, 2016, p. 573).

In 2013, the Australian RCIRCSA was established to investigate how institutions have responded to allegations and instances of child sexual abuse (CSA). Since then, more than 8,000 complainants have shared their stories (RCIRCSA, 2017a).

Several types of cases of CSA have been distinguished on the basis of the setting or context in which offending occurred, for example, parental, intrafamilial, extrafamilial, institutional and noninstitutional offending (Finkelhor, 2009; Goodman-Delahunty, 2014; Parkinson et al., 2017; Sullivan \& Beech, 2004). All have in common that offenders are "in a position of responsibility, trust or power over the victim" (World Health Organisation \& International Society for Prevention of CSA and Neglect, 2006, p. 10). The negative impact of CSA on children's overall health is similar regardless of type of setting. Research indicates CSA induces chronic stress, negatively influences development, and can result in overdevelopment of neurological responses to anxiety and fear (World Health Organisation \& International Society for Prevention of CSA and Neglect, 2006). Studies found correlations between CSA victimization and brain development, such as underdevelopment of complex thoughts and learning processes (World Health Organisation \& 
International Society for Prevention of CSA and Neglect, 2006). Thus, investigating behavioral patterns and strategies of CSA perpetrators is critical to child protection research.

Offenders' formal position of authority over children within an institution gives them ready access to children. The potential for offences committed within an institution to differ significantly from other child sexual offences is implicit in the establishment in many countries and jurisdictions of specific commissions to investigate institutional offending, such as the Commission to Inquire into Child Abuse in Ireland, the RCIRCSA in Australia, the Independent Inquiry into CSA in the United Kingdom and the Royal Commission of Inquiry in New Zealand. Yet little is known about the modus operandi of institutional offenders (McAlinden, 2012) and the extent to which their offending patterns differ from or are similar to those of non-institutional offenders.

One way to explore this question is to systematically examine a sample of CSA cases in each respective context to assess their commonalities and differences. Similar to intrafamilial offenders, institutional offenders have a caretaking role involving some degree of physical or emotional intimacy with children and commit their crimes from a position of authority in loco parentis (Smallbone \& McKillop, 2016) following routine interactions with children (McAlinden, 2012). The thesis of this article is that responsibility over children and abuse of that authority are features in common among both sets of child sexual abusers. However, prior contextual studies have not compared the modi operandi of offenders in institutional versus non-institutional contexts, nor have they provided an in-depth analysis of their offending behaviors. The present study examined these issues.

\section{Offending Strategies with Child Sexual Abuse Victims}

The modus operandi of an offender includes several different aspects, such as victim characteristics, behavior prior to, during and post abuse, and methods to avoid detection (Smallbone $\&$ Wortley, 2001). These aspects were subject to analyses in the present paper in order to identify similarities and dissimilarities between and within child sex offenders in an institutional versus non- 
institutional context and to provide a comprehensive picture of their behavioral offending patterns. Notably, the modus operandi can be considered a stable dynamic factor, implying a slow change over months or years (Bartol \& Bartol, 2008). A particular offending pattern may evolve over time as an offender gains experience or identifies strategies that are more and less effective. In addition, offenders may alter their behavior in response to a victim's behavior, to situational variations, and to developmental changes in a child in cases of protracted abuse.

Strategies applied by child sexual offenders are complex and have been analysed at different temporal stages in the offending process and from different perspectives. These analyses have shown that offending strategies can include grooming of children and their caregivers, a particular sequence or pattern of behaviors (modus operandi), and types of authority exerted over victims (McAlinden, 2012).

Grooming "refers to a preparatory stage of CSA, where an adult gains the trust of a child (and, perhaps, other people of influence in the child's life) in order to take sexual advantage of the child" (Royal Commission into Institutional Responses to Child Sexual Abuse, 2016, p. 23). Grooming of child victims is difficult to discern in part because these behaviors can appear well-intentioned and their purpose can be unclear to observers (Munro \& Fish, 2015). The complexity of the grooming process as described by McAlinden (2012) includes (a) different manipulative and controlling techniques (b) targeting a vulnerable subject (c) in different interpersonal settings (d) with the aim to establish trust, normalize sexual harmful behavior and facilitate exploitation or prohibit exposure (p. 11).

Various models of grooming distinguish discrete stages (a) victim selection, gaining access, developing trust, desensitizing to touch, ensuring compliance; followed by (b) abuse and maintenance of secrecy (Craven, Brown, \& Gilchrist, 2006; McAlinden, 2012; Winters \& Jeglic, 2017; (c) rapport-building and disclosure (Elliott, 2017); and (d) tactics such as seduction and testing, catching by surprise, verbal/physical coercion, masking sex in a game (McAlinden, 2012; 
Pryor, 1996). Common to all models is the view that grooming is a process which assists in strengthening abusive patterns of offending (Craven et al., 2006).

Grooming can entail both psychological and/or physical strategies (i.e., slow progression of touching, stopping when child is distressed, and retreating to a safe point) (Leberg, 1997), and can be directed at children, their environment and/or significant others (Craven et al., 2006). Thus, grooming can be described from the perspective of the context (intra-/extrafamilial), the subject (child, family, community, self), and the mode or strategy (McAlinden, 2012). Grooming and sexual offending appear to be cyclical processes or a sequential progression through various stages, in which some of the earlier elements may recur to ensure compliance of the child (Howitt, 1995; McAlinden, 2012). Therefore, the strategies applied can precede, follow, or be a part of sexual offending itself.

For example, some practitioners who work with sexual offenders have observed that grooming does not always precede offending (McAlinden, 2012) when the first offence is opportunistic rather than pre-planned. Institutional offenders have less need to groom children or their families, because their position often affords them trust, power and ready access to children (McAlinden, 2012). Pre-planning may not precede offending when an intense relationship becomes sexual due to an offender's misinterpretation of the child's feelings or actions (cognitive distortions; Terry, 2006). In these instances, the offender's affirmative decision to abuse the child satisfies the legal element of intent (Terry, 2006), and sexual offending thereafter is pre-planned.

An analysis of over 300 institutional sexual abuse cases in the sports industry revealed three behavioral strategies applied by offenders: (a) intimate, (b) aggressive, and (c) coercive/manipulative (Brackenridge, Bishopp, Moussali, \& Tapp, 2008). Intimate strategies applied affection and attention without use of force. These strategies are readily misconstrued by third parties as consensual because of the absence of evidence of physical force by the offender and of physical resistance by the victim. Aggressive strategies applied physical aggression towards the 
complainant, showing of pornography, and sexual penetration. Socially coercive manipulative strategies included promises to assist the complainant's career development and provision of illicit goods.

Similarities between intimacy and aggression themes were found in studies that characterized behaviors of rapists (Canter \& Heritage, 1990) and child abusers (Canter, Hughes, \& Kirby, 1998). These findings suggest that sex offenders of different types employ a common repertoire of strategies despite differences in offending contexts. A summary of the six key grooming strategies or modi operandi distinguished by prior researchers is included in the results section.

\section{Research Aims}

The present study used information derived from a contemporary sample of prosecutors' case files in three jurisdictions to describe and compare the modi operandi and grooming strategies of institutional and non-institutional child sexual offenders to provide a comprehensive overview of common behaviors culminating in substantiated cases of CSA. Institutional cases were matched with non-institutional cases. The purpose of pairing the cases was to (1) identify common themes in the behavior of child sexual offenders in an institutional and a non-institutional context, (2) provide in-depth insight into offenders' strategies to manipulate children and their caregivers, and (3) examine implications for the development of programs to prevent CSA and treat child sexual offenders and their victims.

\section{Method}

\section{The Study Sample}

Cases described in this article were derived from a larger sample of 59 of the most recent CSA cases referred for prosecution in three Australian states, that is, 20 files from each jurisdiction (New South Wales, Victoria, and Western Australia; prosecutors in New South Wales case requested the return of one file to respond to an appeal lodged in that case). Approval of the production of the files for research was granted by the Human Research Ethics Committees of the 
collaborating universities (Deakin University approval number: 2015-010; Charles Sturt University approval number: 2015/031), and all reviewed cases were de-identified.

Files were produced based on the following inclusion criteria: Ten each of the most recent prosecution files that involved CSA offences, where (1) the alleged abuse occurred before 2010 and the trial occurred after 2010; and (2) both the alleged abuse and trial occurred after 2010. This enabled control for delays in reporting abuse. A total of $10 \%$ of the cases in the study sample $(n=$ 6) were institutional CSA (Cases 1105, 2014, 2015, 2018, 3011), one of which involved cross-over offending (Case 1208), i.e., the victims were both male and female children.

\section{Procedure}

Prosecution case files were manually reviewed by trained research assistants at the premises of the Offices of the Directors of Public Prosecution in each state. Each file contained the following documents: email correspondence, police briefs, witness statements, correspondence related to the complainant, materials produced under subpoena, court documents and/or trial transcripts. A coding scheme used by Lewis, Klettke and Day (2014) was adapted to capture descriptive case features such as critical dates, offence-related information, and information about the complainant. The coding scheme applied in this study is set out in Appendix A.

\section{Coder training.}

Four research assistants were trained using one case example. Each assistant reviewed the case file and applied the coding scheme. Next, each assistant read, coded and summarized two additional case files. Coding discrepancies were discussed by the team to ensure interrater reliability. The agreement rate between coders was acceptable for categorical variables (Krippendorff's alpha $=.74)$ and excellent for continuous variables (Intra-class correlation $=.94)$.

\section{Descriptive Analysis}

The method used to compare the modi operandi in cases of institutional and noninstitutional abuse was a group-based qualitative comparison across cases (Fishman, 2013; 
Timulak, 2009), comprising an embedded (i.e., multiple levels of analyses) multiple-case design (Fishman, 1999). The low number of institutional cases precluded statistical comparisons of institutional and non-institutional cases. A case-oriented qualitative method of analysis allowed consideration of large number of variables (Della Porta, 2008). This approach is suited to investigate complex phenomena such as modi operandi of sexual offenders to yield "an in-depth understanding of historical processes and individual motivations" (Della Porta, 2008, p. 202).

Key information was extracted from case descriptions and case summaries using descriptive criteria specified by Fishman (1999). Offending patterns were identified using qualitative thematic analysis (Braun \& Clarke, 2006) by systematically comparing manifest and latent variables across cases. Cases were arranged according to the manifest theme (see Table 1 below), that is, content present on a surface level (Berg, 1995) or directly observable (Gray \& Densten, 1998).

The qualitative method was applied as recommended by Fishman $(1999,2013)$ and by Lincoln and Guba (1985), modelled in part after that used by Williams (2015). Triangulation (crosschecking) of data addressed credibility (or internal validity) of the analyses. Thick descriptions of cases, detailed analyses of offending and grooming strategies, and their cross-validation by comparisons with existing literature addressed transferability (external validity), dependability (reliability), and confirmability (neutrality) of the findings (Fishman, 1999, 2013; Lincoln \& Guba, 1985).

To give the same weight to institutional and non-institutional cases we selected an equal number of both types of cases for in-depth analysis. Institutional cases were systematically compared with non-institutional cases based on similarities (Ragin, 2004) of (a) gender of the complainant in relation to the accused (i.e., same sex, opposite sex), (b) complainant's age at abuse onset, and (c) offending fact patterns. Cases were matched by age and gender of the complainants because the modus operandi and grooming behavior is influenced by the developmental stage of the 
child (Sanderson, 2004) and gender stereotypes, or gender-specific interests. One additional noninstitutional case was included in the case study sample because the offender had a criminal history of institutional CSA (Case 1208).

\section{Results and Discussion}

The criteria outlined in the method section above yielded a sub-sample of 19 cases involving 29 child victims with one matching case for Case 1105 (male offender, male complainant, 5 years old), six matches for Case 2018 (male offender, female complainant, 9 years old), three matches for Case 3011 (male offender, female complainants, 8, 10, and 11 years old), and three matches for Case 2015 (female offender, male complainant, 12 years old). Next, these cases were paired based on modus operandi fact patterns. One institutional case was unmatched as none of the other cases involved a complainant of corresponding age and gender or offending patterns, which were more typical of workplace sexual harassment (see below) than CSA (Case 2014). The total number of cases comprising the comparative sample is ten (17\% of the prosecution files reviewed). An overview of the manifest themes, matching criteria, paired and unmatched cases is provided in Table 1.

Insert Table 1 near here

The following section presents a detailed description of the paired cases, their similarities and differences, and discusses them in relation to prior research on the modi operandi of child sexual offenders. Paired cases are presented in relation to six manifest offending themes: (a) sexual abuse by a trusted adult in loco parentis (Cases 1105 and 3005); (b) home visits authorized by parents (Cases 2018 and 2020); (c) ambiguous behaviours with sexual motives (Cases 3011 and 3018); (d) pseudo-romance and pseudo-marriage (Cases 2015 and 1202); (e) crossover offending (Case 1208); 
and (f) workplace sexual abuse (Case 2014). Numbered offending strategies used in each refer to the modi operandi listed in Table 2.

Insert Table 2 near here

\section{Sexual Abuse by a Trusted Adult in Loco Parentis}

The institutional case in this pair of cases concerned a church deacon aged 53 years at the time of the alleged sexual abuse of a boy aged five years (Case 1105). Documents in the case file indicated that two other children (a boy and a girl of the same age) had also reported inappropriate touching while in this offender's care.

The deacon allegedly touched the boy's genitals while babysitting on several occasions over a period of 16 months. Typically, the victim was in the deacon's care while his parents attended Sunday services. The deacon purportedly threatened the boy with police arrest if he reported (Strategy 6), a prominent strategy among institutional abusers (McAlinden, 2012). School records documented problem behaviours such as touching other children's genitals, urinating on others' shoes, and outbursts, such as laughing in class. These atypical behaviours prompted his mother to question him, and he disclosed genital touching by the deacon.

The non-institutional case involved a man (48-58 years of age during the period of abuse) who allegedly abused at least four boys aged 5-14 years, who were part of his extended family, or their friends (Case 3005). In one instance, the abuse persisted for ten years, in others, for a shorter period of time, within the 12 months preceding a police report.

The complainants gave similar descriptions of the defendant stroking their genitals at his home or on a camping trip. In one instance, the defendant forced one of the boys to masturbate him. No threats to the complainants were reported. The complainants disclosed the abuse to their parents 
shortly after it occurred. Parents of children unrelated to the offender confronted him without involving the police.

The modi operandi of the institutional and the non-institutional offenders in these cases is coercive and manipulative (Brackenridge et al., 2008). Both misused their position within the church and/or the family circle. No obvious evidence was found of physical aggression, neither could these behaviors be categorized as affectionate.

The deacon's position gave him ready and easy access to children while their parents attended church on Sundays, and at other social and sporting activities organized by the church. No grooming of the victim was apparent. The deacon groomed the complainant's family to gain their trust (Strategy 3) by befriending the family and encouraging contact outside of the church to build rapport (Elliott, 2017). He exchanged phone numbers with the boy's father to get better acquainted, and was given a ride home. The common non-English language background of the family and the deacon cemented their relationship. The deacon had opportunities to be alone with the children (Strategy 2). He attempted to isolate the complainant from his family by inviting the complainant to a sleep-over at his house to gain access to the victim (Strategy 2). This attempt failed when the complainant declined. The deacon used fear and threats to maintain secrecy of the abuse (Strategy $6)$.

The non-institutional abuser gained access to children through family members. Due to his status as the uncle of the complainants' stepfather, there was no need to groom the families of the children. Instead, grooming targeted the boys. The offender kept alluring games at his home that were of interest to boys, such as a pinball machine and computer games in a room with several computers (Strategy 4: reciprocity to ensure compliance). For this reason, the boys kept returning. They seemed to accept abuse as a condition of access to desirable tangible assets. The offender used computer games to provide a legitimate cover story so he could engage in abuse (Strategy 2). In many cases, the offender placed complainants on his lap while they played computer games, and 
touched their genitals. In other instances, he touched them while they were sleeping on a couch or in a tent. Regardless of the location, he created a situation in which he could proclaim an innocent explanation for touching the boys if questioned. These situations gave him the opportunity to gradually habituate victims to nonsexual physical contact before introducing sexual contact (Strategy 5).

The institutional case went to trial twice and ultimately did not proceed. The jury attending the non-institutional case acquitted the defendant of all charges.

\section{Home Visits Authorized by Parents}

This pair of cases involved two offenders, both aged 38 years, who abused a female aged 9 years at the abuse onset (Cases 2018 and 2020). Although the social relationships were different (family priest vs. befriended neighbor) both offenders gained the trust of the parents (Strategy 3), who approved unsupervised visits of the child by the offender. The offenders abused this trust for their personal sexual gratification.

The institutional offender was a family priest who gained the family's trust in several ways. The family attended church services regularly with their children. The priest accepted invitations to visit their home to bless the house, and to watch a sports game with the complainant's father. This increased the rapport and their trust in him, and gave him the opportunity to inspect the premises. The victim selection process was completed when the offender learned that the children were at home unsupervised during the school holidays (Strategy 1). He used this knowledge and his position to gain access to the daughter by attending her home on several occasions under the false pretense of praying (Strategy 2). This behavior resembled the grooming pattern identified as institutional grooming (McAlinden, 2012), namely befriending families and providing special treatment to children with a sexual motive. During these visits, the offender tested the boundaries when he was alone with the complainant (Strategy 5: ambiguous touch, desensitization to touch preceding sexual touch). He started with apparently innocuous behavior by asking the complainant 
to sit on his lap, next stroking her stomach area, and slowly progressed to sexualized behavior, touching her breasts first on top of and then beneath her clothing, and finally touching her vagina. To maintain secrecy, the priest threatened to harm her and her family (Strategy 6: verbal coercion). The non-institutional offender was a neighbor who became a family friend with unlimited access to the family home, irrespective of the presence of the parents (Strategy 2). He knew the hiding-place for the spare house key. As in the institutional case, the parents allowed him unlimited access to their daughter, due to the friendship and mutual spontaneous visits. The physical development of the child may have evoked the offender's sexual interest (Strategy 1: physical characteristics). Thus, the first incident might have been opportunistic, not preplanned (McAlinden, 2012) followed by pre-planned sexual contact. Offending began with low-level contact offences, first kissing, then fondling escalating to digital and oral penetration, and after three years, to penile penetration. The number of offences became increasingly frequent, intense and violent, over a protracted period. The offender had physical and emotional power over the complainant which resembled the aggressive mode of interaction (Brackenridge et al., 2008; Canter et al., 1998). He used different strategies to ensure that the offending remained undisclosed. He used secrecy, told her that he loved her, intimidated her, threatened physical violence if she did not comply with his demands, and threatened to kill her (Strategy 6).

In both cases, the offenders threatened the complainants, which instilled fear in them that persisted years after the offending stopped. Both complainants first disclosed the abuse to a teacher. No actions were taken in the institutional case, and the police were contacted in the non-institutional case. After disclosure of the abuse, four years lapsed before legal action was initiated against the offender in the institutional case. The case was tried by a jury, and the defendant was acquitted.

Despite police involvement in the non-institutional case, leading to temporary relocation of the complainant, and relocation of the offender, the complainant declined to give evidence in court. The most common age at which victims are unwilling to go to trial is 15-19 years (Ferrante, Clare, 
Randell, \& Boyd, 2017). When legal action proceeded 12 years later, the case went to trial three times. The third jury acquitted the defendant.

\section{Ambiguous Situations Created with a Sexual Motive}

In this pair of cases, offenders exploited a legitimate reason for physical proximity and touch to sexually abuse young girls (Cases 3011 and 3018). The comparison revealed a deliberate versus an opportunistic offender with the same modus operandi.

The institutional offender was a priest ( 55 years old) accused of abusing three prepubertal girls (aged 8-11 years) to whom he gained access by organizing activities for children and offering private guitar lessons (Strategy 2). This gave him many opportunities to be alone with the girls. Offending occurred primarily on church grounds, the environment with which he was most familiar. In one case, after private lessons started at the family home, he moved the location to the church or his private rooms nearby.

The modus operandi was as follows: After gaining the trust of the girls, he placed himself behind them, ostensibly hugging them. This physical contact escalated to sexual touch (Strategy 5), of their breasts and/or groin area, while he behaved as if nothing out of the ordinary happened-a strategy known to be used by sex offenders working with children (Leclerc, Proulx, \& McKibben, 2005).

The offender's trusted position as a priest was the main reason his offending was undiscovered. Grooming of the parents may have created cognitive dissonance between concerns about the offender and his acceptance (Craven et al., 2006). The families approved the private sessions, although one family was uncomfortable about unsupervised contact. Secondly, he took the girls to an unfamiliar environment, and at the same time, created ambiguity as to whether his behavior was appropriate. The complainants reported shame and fear that they would not be believed as reasons for failing to report the sexual abuse. 
In one case, the complainant disclosed the abuse to her father after he confronted her about stopping her guitar lessons. The child protection agency warned him against making unsubstantiated or false accusations against a priest without proof. The father concluded that he lacked adequate proof, and discredited the complainant's credibility, calling her a pathological liar. These reactions are consistent with successful grooming where "offenders groom the community so well that if a complainant disclosed their abuse, the community may support the offender rather than the complainant, because they deem the offender to be more believable than the child" (Craven et al., 2006, p. 293). The absence of the complainant's mother (due to her death), may have assisted the priest in gaining access to the complainant and in grooming. Many child sexual offenders deliberately target single-parent families (Elliott, Browne, \& Kilcoyne, 1995), and priests befriend vulnerable families, for example, following the death of a parent (McAlinden, 2012).

The paired non-institutional case involved sexual abuse of two female siblings (aged 9 and 11 years at onset) by their former neighbor (40 years old) and friend of their father. In contrast to the institutional case, the offender did not deliberately create opportunities to abuse the girls. Instead, he seized the opportunity to abuse the girls while they stayed overnight stay at his home.

Similarities in offending behaviors were recounted by the girls. While the complainants were sleeping, he placed his hand under their pajamas and touched their breasts, and in the case of the older sibling, her vagina. Waiting for the girls and their father to fall asleep promoted secrecy (Strategy 6). He provided innocent excuses for his behavior to create confusion and ambiguity about his behaviors (Strategy 5: ambiguous touch, progression of touch), although these did not always make sense, e.g., that he was searching for his wallet, or something next to the bed, or wanted to massage the girls. The offender exploited the existing friendship and trust to abuse the girls when the opportunity presented itself. The fact that the other sibling in the room was asleep provided virtual isolation (Strategy 2) so no further strategies to maintain secrecy were applied. 
Reasons for nondisclosure were fear of their parent's reactions because the offender was a trusted close friend of their father. The older sister partially disclosed (said she was touched), but did not report the full extent as she feared her mother's reaction and that she would get into trouble. The younger sister first thought she had been dreaming, and later, did not want to rupture her father's friendship with the offender. Only when the siblings discussed the offences did they stop blaming themselves. Full disclosure occurred when the mother told both girls they would be staying overnight in the accused's house. The younger complainant refused to go, and after further questioning, described the assault against her. This was followed by her older sister's disclosure. This case demonstrated frequently mentioned reasons that children do not disclose sexual abuse: self-blame and anticipation of disbelief (Esposito, 2014). The disclosure resembled the institutional case in that knowledge of other victims gave them confidence to speak up in a context in which they might be believed.

At trial, the respective juries acquitted the priest in the institutional case and convicted the neighbor in the non-institutional case.

\section{Pseudo-Romance and Pseudo-Marriage}

This pair of cases was matched according the complainants' age and by gender in relation to that of the offender, i.e. victims aged 12 and 13 years at the onset of offending by an adult of the opposite sex (Cases 2015 and 1202). In these cases, offenders behaved as if their relationship was a romance or a marriage, and elevated the children's status to that of an adult partner (Wilson, 1999) and a partner (Leberg, 1997). However, the manner in which the offenders groomed and behaved towards the respective complainants differed considerably. The behavior of the institutional offender was affectionate without signs of aggression, whereas the behavior of the non-institutional offender was predominantly aggressive (Brackenridge et al., 2008; Canter et al., 1998).

The institutional offender was a female school teacher (31 years old at offending onset) at a religious school. She made one of her male students (aged 12 years) believe they were having a 
romantic relationship. The first contact began at a school camp where the teacher developed a sexual interest in the complainant. After the camping trip, she rearranged her classroom so that the complainant was seated very close to her, allowing her to touch him easily without being seen by other students. She also created situations where they were alone (Strategy 2). For instance, she made him stay behind after school and locked the classroom before kissing him. She initiated further meetings outside of school to engage in sexual contact, such as touching and fondling.

The teacher manipulated the complainant via professed love and attention and without coercion or aggression, thus the grooming and sexual behavior was categorized as "intimate" (Brackenridge et al., 2008). Although strategies applied were comparable to those reported by male sexual offenders (Elliott et al., 1995), other research suggests that relational strategies, in particular, are more predominant among female child sex offenders (McAlinden, 2012). The offender isolated the complainant from children of his own age (Strategy 2). She made the complainant believe that he was "special" and that they were romantic partners. She gave him gift cards, and said she wanted to marry him (Strategy 4). The complainant was sexually aroused by certain interactions with the offender. Use of adolescent sexual curiosity is a strategy reported by child sex offenders (Elliott et al., 1995). The teacher used typical offender strategies to establish secrecy (Strategy 6), describing the offending as their "secret" and saying that both of them would get into trouble if he told anyone (Leclerc et al., 2005).

On at least one occasion, a male teacher observed the offender kissing the complainant. Although this was reported to the parish priest, and the police seemed to have had knowledge of it, no legal action ensued. The complainant's parents were informed of the offending and simultaneously told the matter had been dealt with by the school. This institutional response to the CSA allegations is similar to those observed in faith communities (McAlinden, 2006). More than 30 years after the offence, the complainant made an official statement to police which resulted in criminal charges against the offender. 
The non-institutional offender in the paired case was first a dating partner and then the de facto spouse of the complainants' mother, which established trust with the mother and the child (Strategy 3). The assaults commenced in the absence of the mother and escalated some years later when the mother was overseas for six weeks (Strategy 2). The offender successfully disrupted the mother-daughter relationship, so that the mother did not support her daughter when she first disclosed the abuse. Instead, the mother was jealous of the complainant, ended her relationship with the offender, and moved out of the family home, leaving her daughter with the abuser who had legally adopted her. This gave the offender unlimited access to the complainant. The offender asked the complainant to behave as his wife--a strategy often observed in cases of intrafamilial sexual abuse (McAlinden, 2012). He used this access to live out his sexual fantasies, introduced sex toys into the abusive acts, forced the complainant work as a prostitute and give her earnings to him.

The complainant did not resist the assault as he desensitized her to physical contact preceding sexual contact (Strategy 5), and convinced her that this was normal father-daughter behaviour. By the time she realized the opposite, she was unable to resist because of her fear and his level of control over her. The offender's behavior towards the victim appeared so intimate that family and friends suspected it went beyond a father-daughter relationship, but took no action. She asked a friend and later a school counselor whether breast fondling by a father was normal. When the police were contacted she retracted her statement because the offender instructed her not to speak about it as everyone else would be angry with her (Strategy 6: verbal threats). Lack of support from her mother confirmed the offender's suggestions. When the victim was older, her attempts to resist and escape failed as the abuser spiked her drinks, gave her drugs (Strategy 4), or assaulted her violently. The latter resulted in hospitalization on one occasion and criminal charges against the offender. Even then she did not report the sexual abuse. When she was 20 years old, her uncle helped her escape, but another ten years passed before she brought charges against the offender. 
At trial, the juries acquitted the teacher in the institutional case and convicted the step-father of some of the charges in the non-institutional case.

\section{Crossover Institutional and Non-Institutional Offending}

An argument has been made that institutional offenders are unlikely to re-offend because their re-employment will be compromised (Sullivan, Beech, Craig, \& Gannon, 2011; Turner et al., 2014). The following case demonstrated how, following his arrest for CSA, a child sex offender fixated on prepubertal and pubertal boys regained access to boys in this age group by becoming a soccer coach (Case 1208). On all known occasions, he offended against boys under his authority, either as a soccer coach or as their surrogate father. In all known cases, he targeted boys with a missing father figure, so he could "fulfil" this parental role (Strategy 1). He not only asked the boys to call him "dad," but also legally adopted one of them, with the approval of the boy's mother.

The first known series of offences involved sexual misconduct against four boys at a college where he was employed as a soccer coach. The prosecution files did not contain detailed information about the prior victims, limiting analyses of the offender's behavioral patterns. Following publicity of the charges against him, the offender moved to another location where this history was unknown, and sought to gain the trust of boys and of their families in that neighborhood. This case demonstrated successful familial grooming as described by McAlinden (2006) and Salter (2003). First, the offender prepared his house and socialized with multiple boys at a time so that they became interested in spending time with him. He provided different attractive tangible items, and extravagant gifts, such as buying one boy a bicycle (Strategy 4). Simultaneous grooming of multiple children is not uncommon among child sex offenders, as this secures several "readily available" potential victims in case one child breaks off the relationship with the offender (McAlinden, 2012, p. 92). Secondly, the offender persuaded the boys' mothers to trust him to the degree that they allowed their sons to stay at his house overnight (Strategies 2 and 3). In one 
instance, the mother gave the offender full guardianship rights by allowing him to adopt one of her sons.

Once grooming was effective, the offender desensitized the boys to non-sexual, seemingly innocent physical contact (Strategy 5). After the boys were accustomed to physical contact with the offender, his behavior became progressively sexualized, a strategy used by most child sex offenders (Elliott et al., 1995; McAlinden, 2012). For instance, the offender shared a bed with the complainants, showered them, and washed them. These behaviors can appear unproblematic in isolation, as an innocuous alternate explanation was available. Accordingly, discerning whether these behaviors were sexually motivated is difficult (Smallbone, Marshall, \& Wortley, 2008, p. 3). By establishing the rule that "what happens in my house, stays in my house" the offender filtered out boys who were not compliant. A clear progression towards sexual assault emerged: after regular physical contact was successfully initiated, the offender progressed the touching to digital penetration, mutual oral sex, and in one instance, anal sexual intercourse. He instructed the boys not to "tell anyone, as this is father-and-son stuff." When he initiated a new type of sexual contact, he repeated the instruction regarding other offences (Strategy 6). In this way, he exploited the boys' naivety and confused them by asserting that all types of contact were normal between father and son. The absence of a real father figure in the boys' lives assisted in maintaining this deception.

Interestingly, people in the offender's neighborhood assumed or knew about his sexual preference, but none spoke about this to the boys' mothers. This behavior resembled the phenomenon observed by Williams (2015) of the successful grooming of certain families and avoidance of the "knowledgeables" (p. 36). This non-institutional case was discontinued following the death of the soccer coach shortly before the trial date.

\section{Sexual Abuse by a Supervisor}

This institutional case (2014) presented a standard quid pro quo pattern of workplace sexual harassment in which an employment benefit, payment of the worker's wages, is contingent upon 
provision of sexual favors (Foote \& Goodman-Delahunty, 2005). Typically, the abuser is a supervisor or manager who uses that authority to confer benefits to exploit a subordinate (Goodman-Delahunty \& Foote, 2011), in this instance, a vulnerable adolescent employee with little or no workplace experience (Strategy 1: selection based on psychological vulnerability). The case met the criteria for CSA (i.e., the 41-year age difference between the minor complainant and offender) and illustrated how "the concept of sexual harassment overlaps with the concept of (child) sexual abuse" (Kaltiana-Heino, Fröjd, \& Marttunen, 2016, p. 12). Since the context did not entail aspects of grooming and offending that closely resembled those in other reviewed cases, this case was analyzed without a matching non-institutional pair.

The offender was a business owner who sexually abused a 16-year old male adolescent with a possible mild intellectual disability (Case 2014). Like other cases of workplace sexual harassment, a male subordinate was sexually exploited by his direct supervisor (AWARE Sub-Committee on Workplace Sexual Harassment, 2008; Foote \& Goodman-Delahunty, 1999) with ready access to the adolescent (Strategy 2). The disability and naivety of the complainant about the workplace and professional relationships, in addition to his sexual naivety (Strategy 1: vulnerable victim) meant that he lacked awareness of the extent to which the offender's behavior was inappropriate.

Offending began when the complainant reported that his phone was broken. The offender gave him $\$ 700$ to buy a new one, and told him he didn't have to pay it back in cash, as there were other ways to repay him (Strategy 4: reciprocity). This created a sense of obligation in the vulnerable complainant. The first reported offending occurred after a workplace Christmas party where the adolescent was served alcohol. The offender took the drunk child to his home, showered him, and progressed the physical touch to sexual touch (Strategy 5), followed by masturbation of and in front of the complainant while showing him pornography. After the offender successfully abused the inebriated complainant, in the ensuing weeks, he became increasingly demanding and aggressive. He sent the complainant sexual texts and pornographic pictures by phone, and 
demanded that the complainant take photos of his own genitals for the offender. On another occasion, the offender gave the complainant money and demanded masturbation and oral penetration (Strategy 4: reciprocity).

The offender exploited the complainant as much as he could, and behaved as if he owned him. Money played a significant role in justifying his behavior: When the complainant resisted, the offender threatened to withhold his wages, and to harm the complainant's family to maintain the complainant's silence (Strategy 6). At trial, the jury convicted this institutional offender.

\section{Conclusion}

This study compared grooming strategies and modi operandi applied by institutional and noninstitutional child sexual abusers. The proportion of institutional offenders $(10 \%)$ in the study sample was similar to that observed in other larger samples of CSA cases. For instance, police and court data from two Australian states over a period of 11 years $(2003-2014)$ disclosed that $5.6 \%$ of

offenders were persons in authority (Cashmore, Taylor, Shackel, \& Parkinson, 2016). In a study of 305 child sexual offenders $13.4 \%$ were classified as working with children (Sullivan \& Beech, 2004). Prevalence studies showed that between $3 \%$ and $11 \%$ of child sex offenders were women (Cashmore et al., 2016; Denov, 2003; Peter, 2009), a slightly higher proportion than in our sample $(1.7 \% ; 1$ of 59 cases $)$.

Although the precise circumstances of every case of CSA are unique and distinctive, the case studies illustrated very similar and at times, indistinguishable modi operandi in institutional and non-institutional cases. The most prominent strategy among all cases was the physical or emotional isolation of the child to gain access $(100 \%)$. The use of either coercive (threat or actual violence, $60 \%$ ) or noncoercive (affection and love, 30\%) strategies to maintain secrecy (4 institutional, 3 noninstitutional cases, 70\%) was the next most common. Notably, when offenders noticed that strategies of affection and love became less effective, they adopted more aggressive verbal coercion (Case 2015), physical coercion and violent strategies (Cases 1202 and 2020) to maintain victims' 
compliance. Another widely used strategy was the progression of physical contact to sexual contact (3 institutional, 4 non-institutional cases, 70\%). This strategy may have assisted in testing victim compliance and whether they would maintain secrecy (Colton, Roberts, \& Vanstone, 2012; McAlinden, 2012).

Trust development as a systematic strategy ( 2 institutional, 3 non-institutional cases, 50\%) was prevalent in every second case, indicating that while some offenders expended time and effort grooming a child and/or their family, in other instances, the position of the offender within the family or the institution instilled the necessary authority and trust that facilitated abuse (McAlinden, 2012). Further, as was demonstrated by the crossover and versatile offending observed in case 1208 , the offender adapted his modus operandi to continue abusing minors outside of the institution. These findings point to adaptive opportunistic or situational behaviors of both institutional and non-institutional child sex offenders.

Strategies applied by offenders to select victims were less obvious in these cases $(40 \%)$, probably because the records analyzed were derived from the perspectives of victims, not offenders. In several cases, clear vulnerabilities of victims, in addition to their young age, were identified, e.g., family situations, psychological vulnerabilities, inebriation. Finally, reciprocity as a means to secure victim compliance (Craven et al., 2006; McAlinden, 2012) was identified in $40 \%$ of the cases, and was used more by non-institutional or cross-over offenders ( 3 of 5 ) than by institutional offenders, with the exception of the workplace supervisor. In that case, gifts and money were initially provided as incentives, and subsequently this strategy was changed to a threat to withhold wages, or to harm to the victim's family, to secure compliance.

Our systematic analyses of the foregoing paired cases demonstrated that when offending persisted over a protracted period of time, in some instances as long as ten years, it tended to involve more severe offending behaviors, such as penetration (Case 2020, 7 years; Case 1208, 10 years). Less protracted offending more typically entailed preliminary grooming behaviors, and no 
contact or non-penetrative sexual contact (Case 3011). These findings replicated previous research showing that persistent offending was more severe than single abuse events (van Gijn \& Lamb, 2013). Furthermore, our in-depth analyses in the present study of the modi operandi of offenders disclosed how they adapted to contextual factors and changed strategies to continue their abuse (Bartol \& Bartol, 2008). As was demonstrated in case 1208, the offender devised another way to gain access to children when his first means of access was closed. Moreover, although previous research showed that offenders applied either persuasive or coercive techniques (van Gijn \& Lamb, 2013), our comparative analyses of modi operandi in this study sample disclosed that offenders did not utilize a single strategy, but were versatile, and modified their tactics in the course of the abusive relationship to secure ongoing compliance of their victims. For example the offender in case 1202 started with socially persuasive techniques and switched to more coercive strategies when the complainant became resistant, or the offender perceived that the victim might resist.

\section{Limitations of the Study}

The study faced a number of limitations. The amount of detailed information available in the case files varied. Information derived from prosecutors' files was mainly from the perspectives of the complainants, with less information on the defendants' perspectives. Hence, the information might be prone to some distortion. However, studies in which offenders' perspectives were considered revealed that offenders denied some aspects of the abusive acts, minimized the severity of their behavior or rationalized the abusive acts due to cognitive distortions (Marshall, Fernandez, Marshall, \& Serran, 2005; Salter, 1988). Further, it is possible that other strategies applied by offenders (and were not obvious to complainants) were unreported.

As with most reports of childhood sexual abuse, the veracity or ground truth of the reported incidents was not definitively established. Although a false accusation is possible, prior research indicated that children's allegations of sexual abuse were true in $96 \%$ of cases (Oates et al., 2000; Trocmé, Tourigny, MacLaurin, \& Fallin, 2003). Cases in this sample were treated as true 
descriptions of the behavior of child sexual offenders based on police prosecutors' independent determinations that the evidence of abuse was substantiated and sufficient to meet legal standards for conviction. For a case to proceed to trial in Australia, a reasonable prospect of conviction must exist (RCIRCSA, 2017b, p. 328). The disposition of cases in the study sample revealed that a range of outcomes typical of CSA cases, which experience a higher attrition rate at trial than other criminal cases (Fitzgerald, 2006). Accordingly, analyses were not confined to cases in which convictions were obtained.

Although the study sample was small, this limitation was offset by the fact that this was an exhaustive sample of prosecution files from three different jurisdictions within the study period. Accordingly, the sample was not prone to any selection bias.

\section{Implications for Research, Practice and Legal Policy}

Traditional typologies of child sex offender behavior classified the modi operandi according to gender similarities or differences between offenders and victims, i.e., same-sex versus other-sex offenders (Fergusson \& Mullen, 1999). Gender-based typologies are limited in terms of their implications for prevention and therapeutic interventions. An important contribution of this study is its demonstration that a more useful classification criterion to distinguish offenders is age of the child victims. The case studies revealed clear age vulnerabilities. Many victims were aged 9-11 years, when children's curiosity about adulthood and sexuality can be exploited. The foregoing analyses demonstrated that institutional and non-institutional offenders applied similar grooming and offending strategies, and modified these in response to children's reactions and, in cases of prolonged abuse, developmental changes.

In terms of implications for practice, one insight that emerged from analysis of the modi operandi of child sexual offenders is that the offenders most frequently attempted to isolate children physically or emotionally, and then engaged in efforts to maintain secrecy. Isolation of child victims within institutions can be avoided by implementing regulations prohibiting adults from being alone 
with a child. This is more difficult to avoid in a non-institutional context, but education about the risk of isolation can be included in prevention programs. Secondly, prevention programs will be more effective if childhood protection authorities and police interviewers include questions about modi operandi or grooming behaviors when interviewing children who report abuse. Thirdly, the protracted abuse experienced by many of the victims, at times, facilitated by the lack of support from their family members, highlighted the importance within families and schools of overcoming barriers to discussions about sexual matters and experiences.

In sum, the foregoing findings provided a basis for future researchers and policymakers to explore commonalities between institutional and non-institutional offenders. Striking similarities in their offending patterns as documented in the foregoing cases have implications for therapeutic interventions with child victims and offenders, and for sentencing of child sex offenders. 


\section{References}

AWARE Sub-Committee on Workplace Sexual Harassment. (2008). Research Study on Workplace Sexual Harassment. Singapore: AWARE. Accessed from http://d2t11spzrjtif2.cloudfront.net/wpcontent/uploads/AWARE_Research_Study_on_Workplace_Sexual_Harassment.pdf

Bartol, C. R., \& Bartol, A. M. (2008). Introduction to forensic psychology: Research and application (2nd ed.). Thousand Oaks, CA: Sage.

Berg, B. L. (1995). Qualitative research methods for the social sciences (2nd Ed.). Needham Heights, Mass: Allyn and Bacon.

Brackenridge, C. H., Bishopp, D., Moussalli, S., \& Tapp, J. (2008). The characteristics of sexual abuse in sport: A multidimensional scaling analysis of events described in media reports. International Journal of Sport \& Exercise Psychology, 6, 385-406.

Braun, V., \& Clarke, V. (2006.). Using thematic analysis in psychology. Qualitative Research in Psychology, 3, 77-101.

Canter, D., \& Heritage, R. (1990). A multivariate model of sexual offence behavior: Developments in offender profiling. Journal of Forensic Psychiatry, 1, 185-2121.

Canter, D., Hughes, D., \& Kirby, S. (1998). Pedophilia: Pathology, criminality or both? Development of a multivariate model of offence behavior in child sexual abuse. Journal of Forensic Psychiatry, 9, 532-555.

Cashmore, J., Taylor, A., Shackel, R., \& Parkinson, P. (2016). The impact of delayed reporting on the prosecution and outcomes of child sexual abuse cases. Sydney: Royal Commission into Institutional Responses to Child Sexual Abuse. Assessed, 06 March 2018, from https://www.childabuseroyalcommission.gov.au/sites/default/files/file-list/research_report__the_impact_of_delayed_reporting_on_the_prosecution_and _outcomes_of_child_sexual_abuse_cases_and_appendices_-_government_responses.pdf 
Colton, M., Roberts, S., \& Vanstone, M. (2012). Learning lessons from men who have sexually abused children. The Howard Journal, 51, 79-93.

Craven, S., Brown, S., \& Gilchrist, E. (2006). Sexual grooming of children: Review of literature and theoretical considerations. Journal of Sexual Aggression, 12, 287-299.

Della Porta, D. (2008). Comparative analysis: Case-oriented versus variable-oriented research In M. Kieting, \& D. Della Porta (Eds.), Approaches and methodologies in the social sciences: A pluralist perspective (pp. 198-222). Cambridge: Cambridge University Press.

Denov, M. S. (2003). The myth of innocence: Sexual scripts and the recognition of child sexual abuse by female perpetrators. Journal of Sex Research, 40, 303-314.

Elliott, I. A. (2017). A self-regulation model of sexual grooming. Trauma, Violence, \& Abuse, 18, 83-97.

Elliott, M., Browne, K., \& Kilcoyne, J. (1995). Child sexual abuse prevention: What offenders tell us. Child Abuse \& Neglect, 19, 579-594.

Esposito, C. (2014). Child sexual abuse and disclosure: What does the research tell us? New South Wales Department of Family \& Community Services. Assessed, 06 March 2018, from https://www.facs.nsw.gov.au/_data/assets/file/0003/306426/Literature_Review _How_Children_Disclose_Sexual_Abuse-.pdf

Fergusson, D. M., \& Mullen, P. E. (1999). Childhood sexual abuse: An evidence based perspective. Thousand Oaks, CA: Sage Publications.

Ferrante, A., Clare, J., Randell, S., \& Boyd, J. (2017). Police responses to child sexual abuse 20102014: An analysis of administrative data for the Royal Commission into Institutional Responses to Child Sexual Abuse. Report for the Royal Commission into Institutional Responses to Child Sexual Abuse. Accessed, 21 February 2018, from https://www.childabuseroyalcommission.gov.au/sites/default/files/file-list/research_report__police_responses_to_child_sexual_abuse_2010-14_-_government_responses.pdf 
Finkelhor, D. (2009). The prevention of childhood sexual abuse. Future of Children, 19, 169-194.

Fishman, D. (1999). The case for pragmatic psychology. New York: New York University Press.

Fishman, D. (2013). The pragmatic case study method for creating rigorous and systematic, practitioner-friendly research. Pragmatic Case Studies in Psychotherapy, 9, 403-425.

Fitzgerald, J. (2006). The attrition of sexual offences from the New South Wales criminal justice system. Contemporary Issues in Crime and Justice, 92. Sydney: BOCSAR.

Foote, W. E., \& Goodman-Delahunty, J. (1999). Same-sex harassment: Implications of the Oncale decision for forensic evaluations of plaintiffs. Behavioral Sciences \& the Law, 17, 123-139.

Foote, W. E., \& Goodman-Delahunty, J. (2005). Evaluating sexual harassment: Psychological, social, and legal considerations in forensic evaluations. Washington, DC: American Psychological Association.

Goodman-Delahunty, J. (2014). Profiling parental child sex abuse. Trends \& Issues in Crime and Criminal Justice No. 465. Canberra: Australian Institute of Criminology. Assessed, 17 July 2018, from https://aic.gov.au/publications/tandi/tandi465

Goodman-Delahunty, J., \& Foote, W. E. (2011). Evaluation for workplace discrimination and harassment. Oxford, UK: Oxford University Press.

Gray, J. H., \& Densten, I. L. (1998). Integrating quantitative and qualitative analysis using latent and manifest variables. Quality \& Quantity, 32, 419-431.

Howitt, D. (1995). Paedophiles and sexual offences against children. Oxford: John Wiley \& Sons. Independent Inquiry into Child Sexual Abuse. (2016). Report of the internal review. Assessed, 01 March 2017, from https://www.iicsa.org.uk/keydocuments/935/view/IICSA\%20Review\%20Report_Final_alt_v4_ACCESS.pdf

Kaltiana-Heino, R., Fröjd, S., \& Marttunen, M. (2016) Sexual harassment victimization in adolescence: Associations with family background. Child Abuse \& Neglect, 56, 11-19. Leberg, E. (1997). Understanding child molesters: Taking charge. Thousand Oaks, CA: Sage. 
Leclerc, B., Proulx, J., \& McKibben, A. (2005). Modus operandi of sexual offenders working or doing voluntary work with children and adolescents. Journal of Sexual Aggression, 11, $187-$ 195.

Lewis, T. E., Klettke, B., \& Day, A. (2014). The influence of medical and behavioural evidence on conviction rates in cases of child sexual abuse. Journal of Child Sexual Abuse, 23, 431-441.

Lincoln, Y. S., \& Guba, E. G. (1985). Naturalistic inquiry. Newbury Park, CA: Sage Publications.

Marshall, W. L., Fernandez, Y. M., Marshall, L. E., \& Serran, G. A. (2005). Sexual Offender

Treatment: Controversial Issues. West Sussex, UK: John Wiley \& Sons.

McAlinden, A.-M. (2006). 'Setting 'em up': Personal, familial and institutional grooming in the sexual abuse of children. Social \& Legal Studies, 15, 339-362.

McAlinden, A.-M. (2012). 'Grooming' and the sexual abuse of children: Institutional, internet, and familial dimensions. Oxford, UK: Oxford University Press.

Munro, E., \& Fish, S. (2015). Hear no evil see no evil: Understanding failure to identify and report child sexual abuse in institutional contexts. Report for the Royal Commission into Institutional Responses to Child Sexual Abuse. Accessed, 20 October 2017, from https://www.childabuseroyalcommission.gov.au/getattachment/620678bb-6c9d-45da-94c363c4b40e648f/Hear-no-evil,-see-no-evil

Oates, R. K., Jones, D. P., Denson, D., Sirotnak, A., Gary, N., \& Krugman, R. D. (2000). Erroneous concerns about child sexual abuse. Child Abuse \& Neglect, 24, 149-157.

Parkinson, S., Lewig, K., Malvaso, C., Arney, F., Katz, I., \& Newton, B. J. (2017). Child sexual abuse in institutional contexts: The reliability of police data, nature of allegations reported to police, and factors driving reporting rates. Report for the Royal Commission into Institutional Responses to Child Sexual Abuse. Assessed, 17 July, 2018, from https://www.childabuseroyalcommission.gov.au/sites/default/files/file-list/research_report__child_sexual_abuse_in_institutional_contexts_the_reliability_of_police_data_-_causes.pdf 
Peter, T. (2009). Exploring taboos: Comparing male- and female-perpetrated child sexual abuse. Journal of Interpersonal Violence, 24, 1111-1128.

Pryor, D. W. (1996). Unspeakable acts: Why men sexually abuse children. New York: New York University Press.

Ragin, C. C. (2004). Turning the tables: How case-oriented research challenges. In H. E. Brady, \& D. Collier (Eds.), Rethinking social inquiry: Diverse tools, shared standards (pp. 123-138). Roman and Littlefield Publishers Inc.

Royal Commission into Institutional Responses to Child Sexual Abuse. (2016). Consultation paper: Best practice principles in responding to complaints of child sexual abuse in institutional contexts. Accessed, 20 October, 2017, from https://www.childabuseroyalcommission.gov.au/getattachment/4d7005d6-3842-45aa-b9334e2023ded2eb/Complaint-handling-and-response-consultation-paper

Royal Commission into Institutional Responses to Child Sexual Abuse. (2017a). Final report. Accessed, 20 October 2017, from https://www.childabuseroyalcommission.gov.au/final-report Royal Commission into Institutional Responses to Child Sexual Abuse. (2017b). Criminal Justice Report. Parts III-VI. Sydney: Author.

Salter, A. (1988). Treating child sex offenders and victims: A practical guide. Newbury Park, CA: Sage.

Salter, A. (2003). Predators, pedophiles, rapists, and other sex offenders: Who they are, how they operate, and how we can protect ourselves and our children. New York: Basic Books.

Sanderson, C. (2004). The seduction of children: Empowering parents and teachers to protect children from sexual abuse. London: Jessica Kingsley Publishers.

Smallbone, S., Marshall, W. L., \& Wortley, R. (2008). Preventing child sexual abuse: Evidence, policy, and practice. London and New York: Taylor \& Francis. 
Smallbone, S., \& McKillop, N. (2016). Preventing child sexual abuse: A place-based approach. In Y. Smaal, A. Kalafeldos, \& M. Finnane (Eds.), The sexual abuse of children: Recognition and redress (pp. 61-77). Clayton (VIC), Australia: Monash University Publishing.

Smallbone, S., \& Wortley, R. K. (2001). Child sexual abuse: Offender characteristics and modus operandi. Trends \& Issues in Crime and Criminal Justice, 193, 1-6.

Sullivan, J., \& Beech, A. (2004). A comparative study of demographic data relating to intra and extra-familial child sexual abusers and professional perpetrators. Journal of Sexual Aggression: An International, Interdisciplinary Forum for Research, Theory and Practice, 10, 39-50.

Sullivan, J., Beech, A., Craig, L., \& Gannon, T. (2011). Comparing intra-familial and extra-familial child sexual abusers with professionals who have sexually abused children with whom they work. International Journal of Offender Therapy \& Comparative Criminology, 55, 56-74.

Terry, K. J. (2006). Sexual offenses and offenders: Theory, practice, and policy. Canada: Thompson Wadsworth.

Terry, K. J. (2008). Stained glass: The nature and scope of child sexual abuse in the Catholic Church. Criminal Justice \& Behavior, 35, 549-569.

Timulak, L. (2009). Meta-analysis of qualitative studies: A tool for reviewing qualitative research findings in psychotherapy. Psychotherapy Research, 19, 591-600.

Trocmé, N. M., Tourigny, M., MacLaurin, B., \& Fallin, B. (2003). Major findings from the Canadian incidence study of reported child abuse and neglect. Child Abuse \& Neglect, 27, 1427-1439.

Turner, D., Rettenberger, M., Lohmann, L., Eher, R., \& Briken, P. (2014). Pedophilic sexual interests and psychopathy in child sexual abusers working with children. Child Abuse \& Neglect, 38, 326-335.

van Gijn, E. L., \& Lamb, M. E. (2013). Alleged sex abuse victims' accounts of their abusers' modus operandi. Journal of Forensic Social Work, 3, 133-149. 
Williams, A. (2015). Child sexual victimisation: Ethnographic stories of stranger and acquaintance grooming. Journal of Sexual Aggression, 21, 28-42.

Wilson, R. J. (1999). Emotional congruence in sexual offenders against children. Sexual Abuse: A Journal of Research and Treatment, 11, 33-47.

Winters, G. M., \& Jeglic, E. L. (2017). Stages of sexual grooming: Recognizing potentially predatory behaviors of child molesters. Deviant Behavior, 38, 724-733.

World Health Organisation and International Society for Prevention of Child Sexual Abuse and Neglect. (2006). Preventing child maltreatment: A guide to taking action and generating evidence. Geneva, Switzerland: WHO Press. Assessed, 08 February 2017, from http://apps.who.int/iris/bitstream/10665/43499/1/9241594365_eng.pdf 
Appendix.

Coding Scheme Applied to Prosecutors Files in Child Sexual Abuse Cases

\begin{tabular}{|c|c|}
\hline Variable Name & Description \\
\hline File_No & File number \\
\hline Coder & Coder initials \\
\hline Institution & Case type: $1=$ non-institutional; $2=$ institutional (specify) \\
\hline Vic_No & Number of victims \\
\hline Vic_Gender & Victim gender: $1=$ male; $2=$ female $3=$ both \\
\hline Vic_DOB & Victim birth year \\
\hline Vic_Age_Off & Victim age at the time of the abuse \\
\hline Vic_Age_Trial & Victim age at trial \\
\hline Def_Gender & Offender gender: $1=$ male; $2=$ female \\
\hline Def_DOB & Offender birth year \\
\hline Def_Age_Off & Offender age at the time of the abuse \\
\hline Def_Age_Trial & Offender age at trial \\
\hline Offence & $\begin{array}{l}\text { Abuse type: } 0=\text { grooming; } 1=\text { Exposure to pornography/peeping; } \\
2=\text { Attempted exposure; } 3=\text { Noncontact exposure (exhibiting, } \\
\text { masturbating); } 4=\text { Attempted physical contact; } 5=\text { Nonpenetrative } \\
\text { physical (touching, kissing, forcing to touch him); } 6=\text { Attempted } \\
\text { nonpenile penetration; } 7=\text { Nonpenile penetration (oral, digital- } \\
\text { vaginal/penile/anal penetration); } 8=\text { Attempted penile penetration; } \\
9=\text { Penile penetration (penile-oral/vaginal/anal); } 10=\text { possession of } \\
\text { child porn; } 11=\text { production of child porn; } 12=\text { recording of assault }\end{array}$ \\
\hline Offence_Loc & Record where the offence took place \\
\hline Co_Offenders & Number of co-offenders \\
\hline PoliceReport & Date of police report \\
\hline Discl_Comments & Disclosure details \\
\hline Delay_Comments & Comments about disclosure delay \\
\hline Relationship & $\begin{array}{l}\text { Relationship to offender: } 1=\text { stranger; } 2=\text { acquaintance; } 3=\text { former } \\
\text { boyfriend; } 4=\text { family friend/neighbour; } 5=\text { cousin; } 6=\text { sibling (step } \\
\text { included); } 7=\text { teacher/childcare worker/carer; } 8=\text { guardian; } \\
9=\text { uncle/aunt; } 10=\text { grandparent (step included); } 11=\text { stepparent/de- } \\
\text { facto; } 12=\text { biological parent }\end{array}$ \\
\hline Charge_Date & Date defendant was charged \\
\hline Plea & Plea: $0=$ not guilty; $1=$ guilty; $2=$ guilty to some, not guilty to others \\
\hline Case_Disp & $\begin{array}{l}\text { Case disposition: } 0=\text { not proceeded; } 1=\text { guilty plea; } 2=\text { trial by jury; } \\
3=\text { trial by judge }\end{array}$ \\
\hline Verdict & Verdict $0=$ not guilty; $1=$ guilty; $2=$ guilty to some, $N G$ to others \\
\hline Appeal & $\begin{array}{l}\text { Appeal: } 0=\text { no appeal; } 1=\text { appeal during trial by defence; } 2=\text { appeal } \\
\text { during trial by prosecution; } 3=\text { appeal post-trial }\end{array}$ \\
\hline Appeal_Outc & Outcome of appeal \\
\hline Summary & $\begin{array}{l}\text { Write a brief overview of the case: } \\
\text { - Rich description to understand case including allegations, age, } \\
\text { disposition of parties, time of assault events to time of trial } \\
\text { - Information about how young, vulnerable the child is, family } \\
\text { responses, etc. }\end{array}$ \\
\hline
\end{tabular}


Table 1

Overview of Institutional and Non-institutional Cases $(N=19)$

\begin{tabular}{|c|c|c|c|c|c|c|c|}
\hline Case & Type & $\begin{array}{c}\text { Offender } \\
\text { Relationship }\end{array}$ & $\begin{array}{l}\text { Offender } \\
\text { gender }\end{array}$ & $\begin{array}{l}\text { Offender } \\
\text { age }\end{array}$ & $\begin{array}{l}\text { Victim } \\
\text { gender }\end{array}$ & $\begin{array}{l}\text { Victim } \\
\text { age }\end{array}$ & Manifest theme \\
\hline $1105^{1}$ & $\mathbf{I}$ & Church deacon & M & 53 & M & 5 & $\begin{array}{l}\text { Trusted adult in loco } \\
\text { parentis }\end{array}$ \\
\hline $3005^{1}$ & NI & Uncle & M & 48 & M & 5 & $\begin{array}{l}\text { Trusted adult in loco } \\
\text { parentis }\end{array}$ \\
\hline $2018^{2}$ & $\mathbf{I}$ & Family priest & M & 38 & $\mathrm{~F}$ & 9 & $\begin{array}{l}\text { Unsupervised home visits } \\
\text { authorised by parents }\end{array}$ \\
\hline $2020^{2}$ & NI & Neighbour & M & 38 & $\mathrm{~F}$ & 9 & $\begin{array}{l}\text { Unsupervised home visits } \\
\text { authorised by parents }\end{array}$ \\
\hline 3006 & NI & Family friend & M & 41 & $\mathrm{~F}$ & 9 & $\begin{array}{l}\text { Home visit with sexual } \\
\text { intent in mother \& } \\
\text { daughter }\end{array}$ \\
\hline 3016 & NI & Acquaintance & M & 65 & $\mathrm{~F}$ & 9 & $\begin{array}{l}\text { SA while complainant } \\
\text { asleep }\end{array}$ \\
\hline 1108 & NI & Stepfather & M & 31 & $\mathrm{~F}$ & 9 & SA while mother away \\
\hline 2016 & NI & Stepfather & M & 46 & $\mathrm{~F}$ & $9 ; 10$ & $\begin{array}{l}\text { Exhibition followed by } \\
\text { SA while mother away }\end{array}$ \\
\hline 3002 & NI & Father/stepfather & M & 32 & $\mathrm{~F}$ & $9 ; 14$ & SA while mother away \\
\hline $3011^{3}$ & $\mathbf{I}$ & Priest & M & 55 & $\mathrm{~F}$ & $8 ; 10 ; 11$ & Ambiguity in situation \\
\hline $3018^{3}$ & NI & Family friend & M & 41 & $\mathrm{~F}$ & $9 ; 11$ & Ambiguity in situation \\
\hline 2010 & NI & Stepfather & M & 47 & $\mathrm{~F}$ & $8 ; 10 ; 12$ & Sexualised games \\
\hline 2016 & NI & Stepfather & M & 46 & $\mathrm{~F}$ & $9 ; 10$ & $\begin{array}{l}\text { Exhibition, verbalisation } \\
\text { \& SA while mother away }\end{array}$ \\
\hline $2015^{4}$ & $\mathbf{I}$ & Teacher & $\mathrm{F}$ & 31 & M & 12 & Pseudo-romance \\
\hline $1202^{4}$ & NI & Stepfather & M & 43 & $\mathrm{~F}$ & 13 & Pseudo-marriage \\
\hline 1106 & NI & Family friend & M & 53 & $\mathrm{~F}$ & $11 ; 12$ & $\begin{array}{l}\text { SA during overnight-visit } \\
\text { with father }\end{array}$ \\
\hline 2007 & NI & Stepfather & M & 31 & $\mathrm{~F}$ & 12 & "Sex education" \\
\hline 2014 & $I$ & Employer & M & 57 & M & 16 & Quid pro quo \\
\hline 1208 & $I / N I$ & $\begin{array}{l}\text { Soccer coach/ } \\
\text { friend/neighbour }\end{array}$ & M & 24 & M & $7 ; 14$ & Parental role \\
\hline
\end{tabular}

Note. $\mathrm{F}=$ female; $\mathrm{I}=$ institutional; $\mathrm{NI}=$ non-institutional; $\mathrm{M}=$ Male; $\mathrm{SA}=$ sexual abuse. Offender and victim age is at abuse onset. In cases of multiple victims, age is reported for each victim. Boldface with superscript numbers signify matching cases; italics signify unmatched cases. 
Table 2

Strategies of Child Sex Offenders in Institutional and Non-institutional Cases $(N=10)$

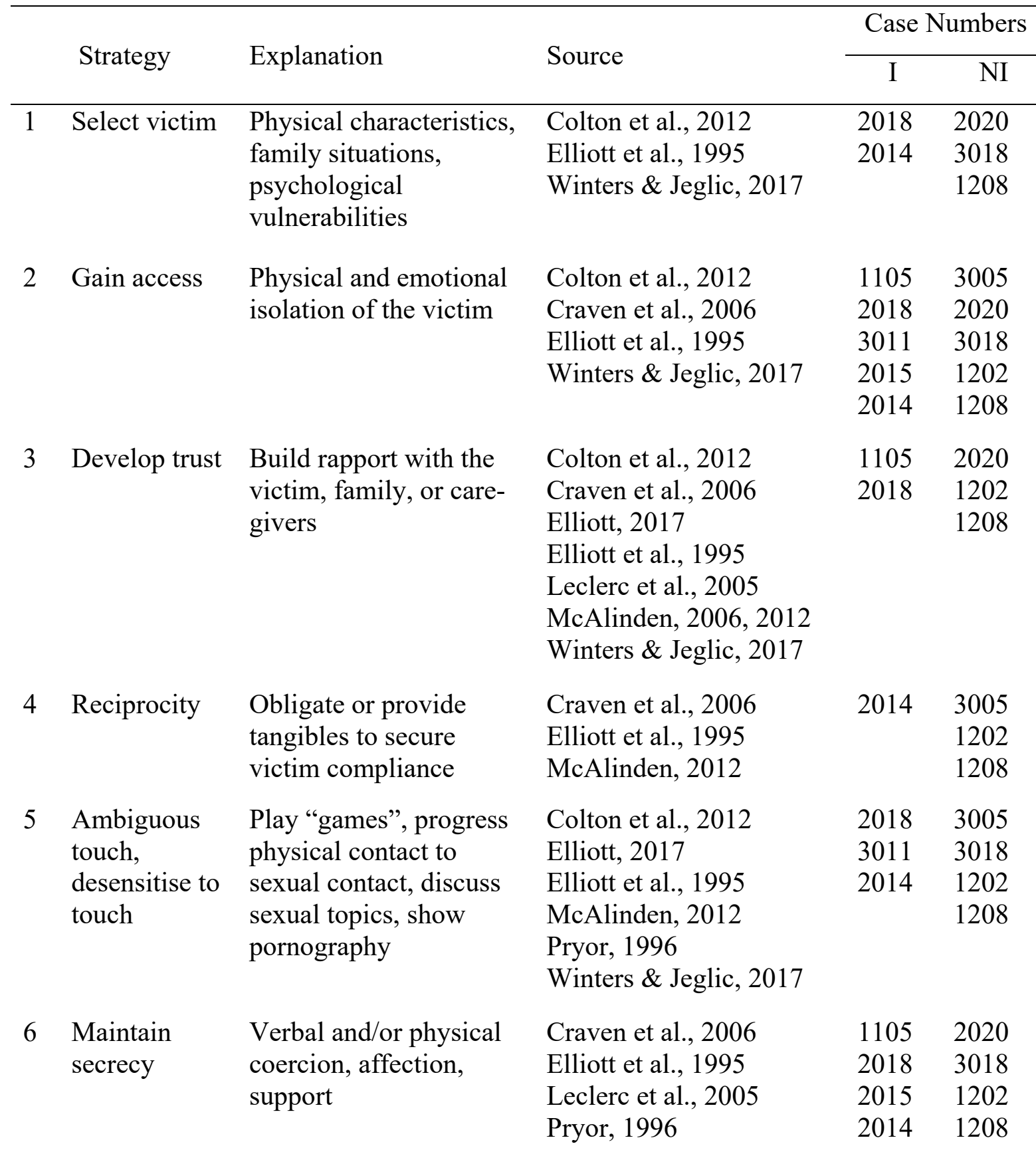

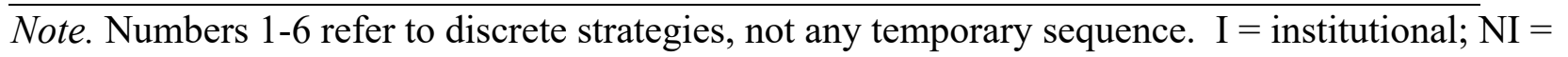
non-institutional. 